\title{
STUDIES ON THE FIRST DERIVATIVE OF THE VENTRICULAR PRESSURE PULSE IN MAN
}

\author{
By WILLIAM L. GLEASON AND EUGENE BRAUNWALD
}

(From the Cardiology Branch, National Heart Institute, Bethesda, Md.)

(Submitted for publication August 5, 1961 ; accepted September 14, 1961)

The rate at which the ventricular pressure rises has been of interest to investigators for many years $(1,2)$. Wiggers demonstrated that when ventricular end-diastolic filling pressure was elevated by increasing the venous return to the heart or the resistance to ventricular ejection, the rate of rise of ventricular pressure also increased (3). When epinephrine (4) or digitalis (5) was administered the rate of pressure rise increased despite a fall in ventricular end-diastolic pressure. Conversely, when myocardial ischemia was induced, the slope of the ventricular pressure rise decreased in the face of a rising end-diastolic pressure (6). More recently, although further observations have been made in the dog on the determinants of the slope of the ventricular pressure pulse (7-11), there have been no systematic studies of the effects of physiologic stresses, pharmacologic agents, and various types of heart disease on the slope of the ventricular pressure pulse in man.

Accurate determinations of the instantaneous rate of ventricular pressure change in intact human subjects have been prevented by the technical limitations imposed by the pressure-recording systems that are usually employed in cardiac catheterization. These systems, which consist of a fluid-filled catheter and an external manometer, have a very limited range in which the frequency response is uniform (usually to less than $15 \mathrm{cy}-$ cles per second) and they are subject to frequent artifacts related to motion of the catheter within the heart. Such artifacts may be manifest as sudden changes in pressure and will therefore be greatly exaggerated when their first derivative is computed. These difficulties have been largely eliminated by obtaining the ventricular pressure tracings with a catheter that has a high-frequency micromanometer mounted at its tip, or by direct needle puncture of the ventricle.

\section{METHODS}

Percutaneous puncture of the left ventricle was carried out by the method of Brock, Milstein and Ross (12) as modified in this laboratory (13). All such tracings were obtained with a 3.5 -inch no. 19 or 20 gage thin-walled needle attached directly to a Statham P23D pressure transducer without intervening tubing. All other studies from either the left or right ventricle were carried out with a Telco intracardiac manometer ${ }^{1}(14,15)$. This instrument consists of a double-lumen catheter, one lumen of which carries the electrical connection to the micromanometer mounted at the tip, the other serving as a conventional fluid-filled catheter system which is attached to a Statham P23D manometer. The sensitivities of the micromanometer and the external manometer were equalized with an air-pressure calibrating system prior to the introduction of the catheter into the heart. The catheter tip was placed in the right or left ventricle and simultaneous pressure pulses were recorded from the two manometers. The baseline for the micromanometer was made equal to that of the external manometer by superimposing the diastolic portions of the two ventricular pressure pulses.

The frequency responses of the micromanometer and of the needle directly attached to the strain gage were analyzed in a fluid-filled chamber in which a sinusoidal pressure wave of variable frequency was generated. The pressure produced was monitored by a Lilly capacitance manometer built directly into the chamber. Figure 1 illustrates a comparison of the pressures recorded simultaneously from the fluid-filled lumen of the Telco catheter, using a Statham P23D strain gage as the external manometer, the Lilly manometer, and the Telco micromanometer. It is apparent that, while the response of the conventional external manometer system resonates at 7 cycles per second $(\mathrm{c} / \mathrm{sec})$ and becomes significantly attenuated at frequencies above $10 \mathrm{c} / \mathrm{sec}$, the micromanometer maintains an almost uniform response, indistinguishable from the Lilly manometer, to frequencies as high as $200 \mathrm{c} / \mathrm{sec}$. With an identical method for comparison it was observed that the needle attached to the P23D gage maintained a uniform response to a frequency of $40 \mathrm{c} / \mathrm{sec}$.

The rate of change of the ventricular pressure pulses (dp/dt) was continuously determined with an R-C differentiating circuit, consisting of a 47 kilo-ohm resistor and a 0.002 microfarad condenser as outlined elsewhere (16). The time constant of this circuit is $9.4 \times 10^{-5} \mathrm{sec}-$ ond, and it provides differentiation of linear amplitude without phase distortion to $50 \mathrm{c} / \mathrm{sec}$. The differentiating circuit was calibrated by imposing a signal of constant and known slope from an integrating amplifier and measuring the resulting response of the differentiator.

1 Telco, Inc., Gentilly, France. Distributed in the U.S.A. by Dallons Laboratory, Inc., Los Angeles, Calif. 


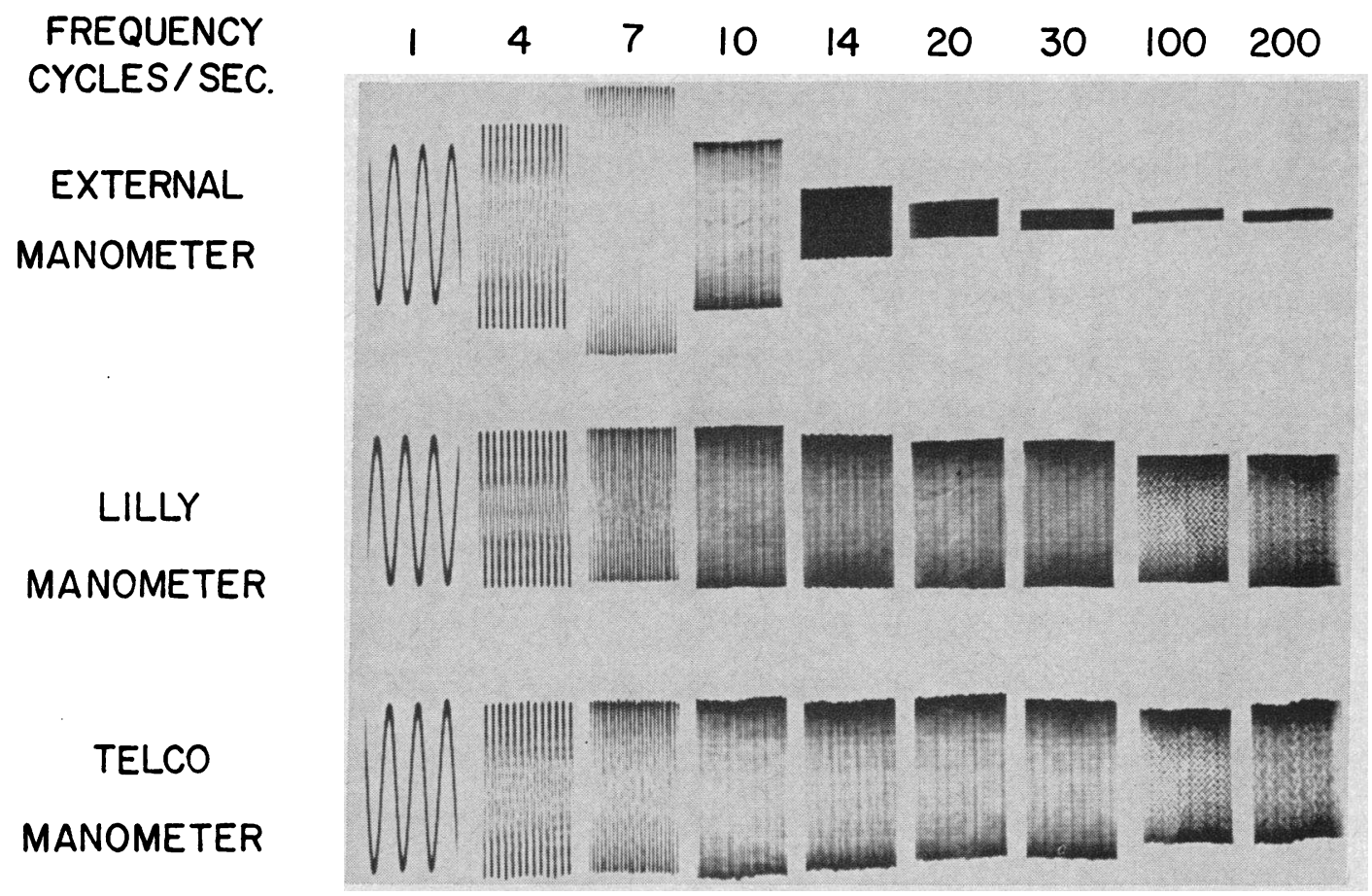

Fig. 1. Simultaneous recordings of pressures from a fluid-filled Chamber through three TRANSDUCERS AT FREQUENCIES RANGING FROM 1 TO 200 CYCLES PER SECOND. The external manometer resonates at $7 \mathrm{c} / \mathrm{sec}$ and its response falls off rapidly thereafter. It is likely that the equal diminution of the amplitude responses of both the Lilly and Telco manometers at $100 \mathrm{c} / \mathrm{sec}$ reflects a decrease in the amplitude of the generated sine wave.

The first derivative of the ventricular pressure pulse was determined in a total of 40 patients, in some of whom it was recorded in both ventricles. In 13 patients percutaneous puncture of the left ventricle was carried out (13) and in a total of 21 patients, including all 17 patients in whom right ventricular $\mathrm{dp} / \mathrm{dt}$ was recorded, the Telco micromanometer was used. Four patients with patent ductus arteriosus and 2 patients with mitral stenosis were studied by direct puncture of the left ventricle at the time of thoracotomy. In the patients with patent ductus arteriosus the effects of clamping and of releasing the ductus were observed. Congenital or rheumatic heart disease was present in most of the patients studied in the catheterization laboratory (Tables I and II). Eight patients had experienced congestive heart failure prior to study and had roentgenographic evidence of ventricular enlargement; in 6 of these the ventricular end-diastolic pressure was distinctly elevated. Thirty-two of the patients studied were in sinus rhythm and 8 had atrial fibrillation.

The cardiac abnormalities present were divided by the type of hemodynamic burden which they imposed on the ventricle. It is fully recognized that considerable variation in the state of ventricular function existed in different patients in the same group and that alterations in ventricular performance were induced by anethesia and thoracotomy in the patients who were studied under these conditions. Nonetheless, it was felt that by dividing the

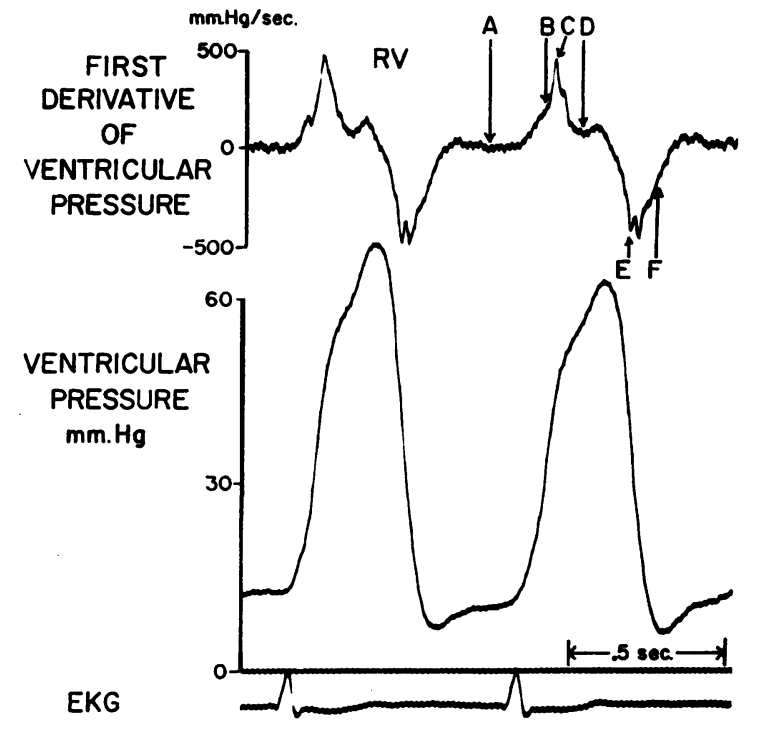

Fig. 2. Simultaneous Recordings of the Right venTRICULAR PRESSURE PULSE, THE FIRST DERIVATIVE OF THE RIGH T VENTRICULAR PRESSURE, AND THE ELECTROCARDIOGRAM IN A PATIENT WITH MITRAL REGURGITATION, ATRIAL FIBRILLATION AND PULMONARY HYPERTENSION. The various portions of the first derivative are labeled and discussed in the text. 
patients into three groups the gross effects of chronic elevations of systolic pressure and of stroke volume on $\mathrm{dp} / \mathrm{dt}$ could be discerned. Group A consists of 15 patients in whom the ventricle in which $\mathrm{dp} / \mathrm{dt}$ was determined did not have an abnormally increased hemodynamic burden and includes 4 patients with mitral stenosis, 5 with atrial septal defect, and 1 after complete abolition of an aortic pressure gradient in whom the left ventricle was studied. In addition, in group $A$ there were 3 patients without hemodynamic evidence of heart disease and 2 with abnormalities involving the left side of the heart but without pulmonary hypertension, in whom $\mathrm{dp} / \mathrm{dt}$ was determined in the right ventricle. Group B consists of 18 patients in whom the ventricle which was studied was subject to a chronically augmented flow load. In this group there were 5 patients with mitral regurgitation, 5 with aortic regurgitation, and 4 with patent ductus arteriosus in whom the left ventricular $\mathrm{dp} / \mathrm{dt}$ was recorded, as well as 3 patients with atrial septal defect and 1 with ventricular septal defect in whom the right ventricular $\mathrm{dp} / \mathrm{dt}$ was determined. Group $\mathrm{C}$ consists of the 11 patients in whom the $\mathrm{dp} / \mathrm{dt}$ was determined in ventricles which developed a distinctly elevated systolic pressure (increased pressure load). This group consists of 3 patients with aortic stenosis in whom the left ventricle was studied, and 5 patients with pulmonary hypertension and 3 patients with pulmonic stenosis in whom the right ventricle was studied.

During the control observations the patients were asked to relax and to suspend respiration briefly while the electrocardiogram, ventricular pressure and $\mathrm{dp} / \mathrm{dt}$ were recorded with a multichannel photographic oscilloscopic recorder. In a number of patients without abnormal hemodynamic burdens the effects of a variety of acute in-

TABLE I

Peak left ventricular $d p / d t$ *

\begin{tabular}{|c|c|c|c|c|c|c|c|c|c|}
\hline $\begin{array}{l}\text { Patient } \\
\text { Method }\end{array}$ & Diagnosis & $\begin{array}{l}\text { Peak } \\
\mathrm{dp} / \mathrm{dt}\end{array}$ & $\begin{array}{l}\text { Heart } \\
\text { rate }\end{array}$ & $\begin{array}{c}\text { LV } \\
\text { pressure } \\
\text { s/d }\end{array}$ & $\begin{array}{l}\text { Patient } \\
\text { Method }\end{array}$ & Diagnosis & $\begin{array}{c}\text { Peak } \\
\mathrm{dp} / \mathrm{dt}\end{array}$ & $\begin{array}{l}\text { Heart } \\
\text { rate }\end{array}$ & $\underset{\substack{\text { pressure } \\
\text { s/d }}}{{ }_{\text {s. }}}$ \\
\hline \multicolumn{5}{|c|}{ Group A, normal LV load } & \multicolumn{5}{|c|}{ Group B, increased LV flow load } \\
\hline $\begin{array}{l}\text { A.T. } \\
\text { OR }\end{array}$ & $\mathrm{MS} ; \mathrm{TS} ; \mathrm{AF}$ & 1,032 & 67 & $120 / 8$ & J.E.S. & MI ; ASD & 1,615 & 95 & $110 / 9$ \\
\hline $\begin{array}{l}\text { O.M.H. } \\
\text { LVP }\end{array}$ & $\mathrm{MS} ; \mathrm{AF}$ & 1,439 & 96 & $97 / 9$ & $\begin{array}{l}\text { A.R.L. } \\
\text { LVP }\end{array}$ & $\mathrm{MI} ; \mathrm{AF}$ & 1,276 & 73 & $109 / 7$ \\
\hline $\begin{array}{l}\text { G.L.W. } \\
\text { OR }\end{array}$ & $\mathrm{MS} ; \mathrm{AF}$ & 1,385 & 89 & $118 / 9$ & $\begin{array}{l}\text { V.E.R. } \\
\text { LVP }\end{array}$ & $\mathrm{MI} ; \mathrm{AI} ; \mathrm{AF}$ & 1,076 & 79 & $120 / 3$ \\
\hline N.E.D. $\dagger$ & \multirow{2}{*}{$\begin{array}{l}\text { MS; AF; } \\
\text { dilated LV } \\
\text { Preop. } \\
\text { Postop. }\end{array}$} & \multirow[b]{2}{*}{$\begin{array}{r}1,300 \\
878\end{array}$} & \multirow[b]{2}{*}{$\begin{array}{l}90 \\
86\end{array}$} & \multirow[b]{2}{*}{$\begin{array}{l}114 / 15 \\
108 / 21\end{array}$} & $\begin{array}{l}\text { W.W.G.† } \\
\text { LVP }\end{array}$ & AI severe & 1,252 & 90 & $141 / 9$ \\
\hline LVP & & & & & $\begin{array}{l}\text { L.M.L. } \\
\text { LVP }\end{array}$ & AI moderate & 1,284 & 87 & $127 / 10$ \\
\hline J.P.H. & $\begin{array}{l}\text { ASD; } \\
\text { normal LV }\end{array}$ & 1,009 & 88 & $99 / 7$ & $\begin{array}{l}\text { E.J.I. } \dagger \\
\text { LVP }\end{array}$ & AI very severe & 1,223 & 102 & $160 / 35$ \\
\hline J.Y. & $\begin{array}{l}\text { ASD; } \\
\text { normal LV }\end{array}$ & 841 & 71 & $83 / 8$ & $\begin{array}{l}\text { B.J.McC. } † \\
\text { LVP }\end{array}$ & AI severe & 1,308 & 92 & $138 / 10$ \\
\hline $\begin{array}{l}\text { D.A.T. } \\
\text { TC }\end{array}$ & $\begin{array}{l}\text { Postop. AS; } \\
\text { no gradient }\end{array}$ & 1,696 & 107 & $103 / 3$ & $\begin{array}{l}\text { J.M.B. } \\
\text { LVP }\end{array}$ & $\mathrm{MI} ; \mathrm{AF}$ & 975 & 86 & $98 / 5$ \\
\hline$\underset{\text { TC }}{\text { A.B.C. }}$ & $\begin{array}{l}\text { ASD; } \\
\text { normal LV }\end{array}$ & 1,611 & 105 & $95 / 8$ & $\begin{array}{l}\text { W.R.A.† } \\
\text { LVP }\end{array}$ & AI severe & 920 & 74 & $116 / 29$ \\
\hline $\begin{array}{l}\text { C.W.C. } \\
\text { TC }\end{array}$ & $\begin{array}{l}\text { ASD; } \\
\text { normal LV }\end{array}$ & 943 & 58 & $87 / 6$ & \multicolumn{5}{|c|}{ Group $C$, increased LV pressure load } \\
\hline M.J.S. & $\begin{array}{l}\text { ASD; } \\
\text { normal LV }\end{array}$ & 938 & 86 & $96 / 6$ & $\underset{\text { LVP }}{\text { J.L.W. }}$ & $\begin{array}{l}\text { AS, gradient } \\
41 \mathrm{~mm} \mathrm{Hg}\end{array}$ & 2,150 & 107 & $155 / 9$ \\
\hline \multicolumn{5}{|c|}{ Group B, increased LV flow load } & LVP & $\begin{array}{l}\text { AS, gradient } \\
62 \mathrm{~mm} \mathrm{Hg}\end{array}$ & 3,239 & 103 & $186 / 15$ \\
\hline $\begin{array}{l}\text { G.R.P. } \\
\text { LVP }\end{array}$ & $\mathrm{MI} ; \mathrm{AF}$ & 1,355 & 108 & $96 / 8$ & $\begin{array}{l}\text { L.D.S. } \\
\text { LVP }\end{array}$ & $\begin{array}{l}\text { AS, gradient } \\
50 \mathrm{~mm} \mathrm{Hg}\end{array}$ & 2,080 & 94 & $156 / 24$ \\
\hline
\end{tabular}

* Abbreviations $: \mathrm{dp} / \mathrm{dt}=$ first derivative of pressure pulse; $\mathrm{s} / \mathrm{d}=$ systolic/diastolic in $\mathrm{mm} \mathrm{Hg} ; \mathrm{LV}=$ left ventricle; $\mathrm{MS}=$ mitral stenosis; TS = tricuspid stenosis; $\mathrm{AF}=$ atrial fibrillation; $\mathrm{ASD}=$ atrial septal defect; $\mathrm{MI}=$ mitral insufficiency; $\mathrm{AI}=$ aortic insufficiency; $\mathrm{AS}=$ aortic stenosis; $\dagger=$ patients with clinical evidence of myocardial failure; $\mathrm{LVP}=$ percutaneous left ventricular puncture; $\mathrm{OR}=$ study done in operating room at time of thoracotomy; TC $=$ Telco catheter study. 
terventions on the ventricular $\mathrm{dp} / \mathrm{dt}$ were also determined. The pharmacologic agents studied included isoproterenol, norepinephrine, methoxamine, and atropine. Whenever the effects of more than one drug were examined, sufficient time was allowed between studies for the results of the previously injected drug to disappear completely. The effects of exercise in the supine position were studied in 2 patients who were asked to pedal a stationary bicycle ergometer vigorously for 2 minutes.

\section{RESULTS}

\section{Contour of $d p / d t$}

The contour of the first derivative of the ventricular pressure pulse is, in general, similar in both ventricles. During ventricular diastole, when the rate of change of ventricular pressure is slow, $\mathrm{dp} / \mathrm{dt}$ is flat and at a level of 0 or slightly greater (point $\mathrm{A}$ in Figure 2). With the onset of isometric ventricular contraction in the left ventricle, dp/dt increases slowly for several milliseconds and then rises smoothly to reach its peak $\left(P D_{L V}\right)$ near the midpoint of the isovolumetric contraction period. In the right ventricle, $\mathrm{dp} / \mathrm{dt}$ exhibits either a notch or an inflection on its ascending limb (B, Figure 2) and usually reaches its peak $\left(\mathrm{PD}_{\mathrm{Rv}}\right)$ at a point higher $(C)$ than the midpoint of the ascending limb of the ventricular pressure pulse; during early ventricular ejection $\mathrm{dp} / \mathrm{dt}$ descends to a level either slightly above or below the baseline and then remains relatively flat during mid and late ejection (D). It begins to fall abruptly to values far below zero during late systole, reaching its nadir early during isovolumetric relaxation $(\mathrm{E})$. Later during isovolumetric relaxation the rate of pressure fall diminishes and $\mathrm{dp} / \mathrm{dt}$ again returns to the baseline $(\mathrm{F})$.

\section{Values for $P D_{L V}$}

The peak values of the ascending limb of $\mathrm{dp} / \mathrm{dt}$ in the left ventricular pressure pulse recorded during the control period are presented in Table I; these values ranged from 841 to $3,239 \mathrm{~mm} \mathrm{Hg}$ per second. In the ten patients without an abnormal hemodynamic load on the left ventricle (group A), $\mathrm{PD}_{\mathrm{LV}}$ varied from 841 to 1,696 , with an average of $1,219 \mathrm{~mm} \mathrm{Hg}$ per second. In the patients in whom the left ventricular stroke volume was chronically augmented (group B) the values for $\mathrm{PD}_{\mathrm{LV}}$ were in a similar range $(920$ to 1,615 ; average, 1,228.) The $P D_{L V}$ in patients with an eleva-
TABLE II

Peak right ventricular $d p / d t$ *

\begin{tabular}{|c|c|c|c|c|}
\hline Patient & Diagnosis & $\begin{array}{l}\text { Peak } \\
\mathrm{dp} / \mathrm{dt}\end{array}$ & $\begin{array}{l}\text { Heart } \\
\text { rate }\end{array}$ & $\underset{\substack{\text { RV } \\
\text { s/d }}}{\text { s/d }}$ \\
\hline \multicolumn{5}{|c|}{ Group A, normal RV load } \\
\hline $\begin{array}{l}\text { J.E.W. } \\
\text { F.W.M. } \\
\text { L.C.J. } \\
\text { L.B.H. } \\
\text { J.V.G. }\end{array}$ & $\begin{array}{l}\text { AS; AI } \\
\text { Hyp } \\
\text { MS; TS } \\
\text { Funct M } \\
\text { Postop. ASD }\end{array}$ & $\begin{array}{l}263 \\
229 \\
230 \\
223 \\
296\end{array}$ & $\begin{array}{r}87 \\
79 \\
77 \\
111 \\
83\end{array}$ & $\begin{array}{l}22 / 6 \\
22 / 3 \\
25 / 3 \\
23 / 3 \\
33 / 0\end{array}$ \\
\hline \multicolumn{5}{|c|}{ Group B, increased RV flow load } \\
\hline $\begin{array}{l}\text { J.E.S. } \\
\text { R.F. } \\
\text { A.B.C. } \\
\text { J.P.H. }\end{array}$ & $\begin{array}{l}\text { ASD; MI } \\
\text { VSD } \\
\text { ASD } \\
\text { ASD }\end{array}$ & $\begin{array}{l}520 \\
309 \\
459 \\
334\end{array}$ & $\begin{array}{r}92 \\
86 \\
107 \\
85\end{array}$ & $\begin{array}{l}42 / 5 \\
31 / 0 \\
34 / 6 \\
34 / 7\end{array}$ \\
\hline \multicolumn{5}{|c|}{ Group $C$, increased $R V$ pressure load } \\
\hline $\begin{array}{l}\text { G.S. } \dagger \\
\text { L.D.C. } \\
\text { O.F.C. } \\
\text { S.K.H. } \\
\text { K.M.M. } \\
\text { T.S.† }\end{array}$ & $\begin{array}{l}\text { Idiopathic PH } \\
\text { PS } \\
\text { MS; PH } \\
\text { PS; VSD } \\
\text { PS } \\
\text { Hodgkin's dis.; } \\
\text { myocard. infilt.; } \\
\text { PH }\end{array}$ & $\begin{array}{l}382 \\
823 \\
646 \\
639 \\
489 \\
422\end{array}$ & $\begin{array}{r}77 \\
64 \\
71 \\
87 \\
87 \\
107\end{array}$ & $\begin{array}{c}53 / 7 \\
121 / 7 \\
58 / 6 \\
69 / 2 \\
51 / 9 \\
53 / 11\end{array}$ \\
\hline $\begin{array}{l}\text { J.M.B. } \\
\text { M.J.S.† }\end{array}$ & $\begin{array}{l}\text { MI ; PH } \\
\text { ASD; PH }\end{array}$ & $\begin{array}{l}472 \\
471\end{array}$ & $\begin{array}{l}81 \\
85\end{array}$ & $\begin{array}{l}59 / 12 \\
77 / 8\end{array}$ \\
\hline
\end{tabular}

* Abbreviations same as in Table I, plus: VSD = ventricular septal defect; $\mathrm{PS}=$ pulmonary stenosis; $\mathrm{PH}=$ pulmonary hypertension; Hyp = systemic hypertension; Funct $\mathrm{M}=$ functional murmur.

tion of left ventricular systolic pressure (group C) tended to be much higher $(2,080$ to 3,239$)$ than in groups $\mathrm{A}$ and $\mathrm{B}$.

\section{Values for $P D_{R V}$}

The peak values for the first derivative of the ascending limb of the right ventricular pressure pulse recorded during the control period in patients without an abnormal hemodynamic load on the right ventricle (Table II, group A) ranged from 223 to $296 \mathrm{~mm} \mathrm{Hg}$ per second. In patients with right ventricular stroke volume greatly augmented but only a slight elevation of right ventricular systolic pressure (group B), these values ranged from 309 to 520 . In patients with an increase in the pressure load on the right ventricle (group $\mathrm{C}$ ) the $\mathrm{PD}_{\mathrm{RV}}$ ranged from 382 to $823 \mathrm{~mm}$ $\mathrm{Hg}$ per second.

It is thus apparent that the values for the $\mathrm{PD}$ of the ventricular pressure pulse varied widely among various patients and that the values in the left ventricle exceeded those observed in the right ventricle. The large variations of PD are attributable, 


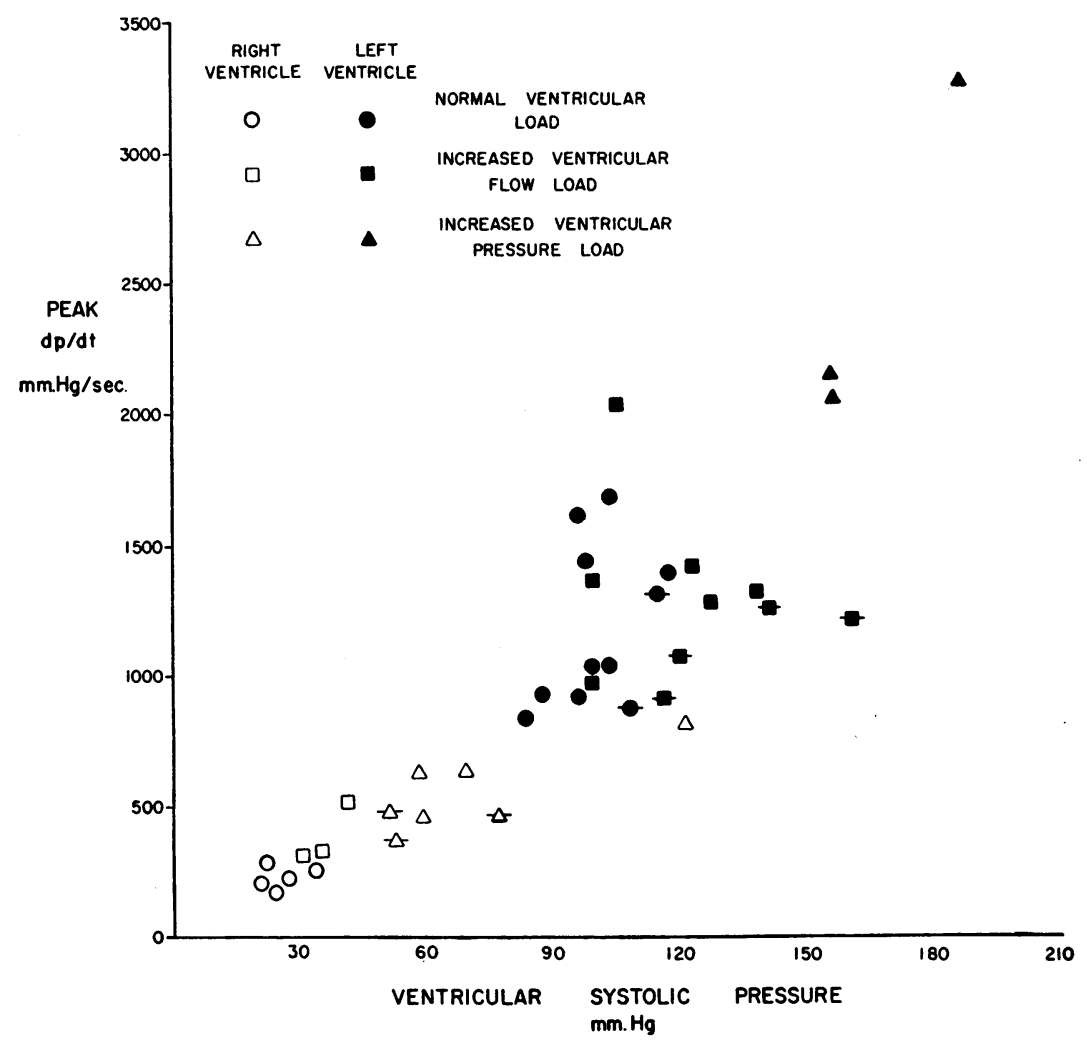

Fig. 3. Relationship BetWeEN PD and the Ventricular systolic PRessure. The symbols with the horizontal lines represent the patients who had marked ventricular enlargement and had experienced congestive heart failure, as described in the text. The correlation coefficient and regression lines were calculated without inclusion of the data from these patients; the formula for the regression line is: $\mathrm{PD}=15.3$ systolic pressure -254 .

at least in part, to the diversity of cardiovascular abnormalities present in the patients who were studied, as well as the conditions existing at the time of study. Nonetheless, it was observed in both ventricles that the $\mathrm{PD}$ tended to be higher in patients with elevation of intraventricular systolic pressure than in those without. When the PD was related to the peak ventricular pressures, a significant correlation ( $r=0.85)$ was evident (Figure 3). It was also observed that at any given ventricular systolic pressure, the $\mathrm{PD}$ was a function of the heart rate. Accordingly, when $\mathrm{PD}$ was related to the product of the systolic pressure and heart rate, a somewhat better correlation $(r=0.92)$ was evident (Figure 4). The data obtained from the patients with clinical evidence of marked myocardial failure tended to fall to the right of the regression lines in Figures 3 and 4; i.e., their PD's were relatively low for their systolic pressures and heart rates. When these patients were excluded from analysis, the coefficient of correlation between systolic ventricular pressure and $\mathrm{PD}$ rose to 0.91 (Figure 3 ) and between the product of systolic pressure and heart rate and PD it rose to 0.97 (Figure 4).

\section{Effects of acute intervention}

a) Drugs. Isoproterenol (1.5 $\mu$ g intravenously) resulted in a striking increase in the $\mathrm{PD}$ in all four patients to whom it was administered (Table III and Figure 5). A clear-cut increase in heart rate was produced in only one of these four patients. Methoxamine, in doses that raised left ventricular systolic pressure between 25 and 37 $\mathrm{mm} \mathrm{Hg}$, and slowed the heart rate by an average of 11 beats per minute, had no significant effect on 


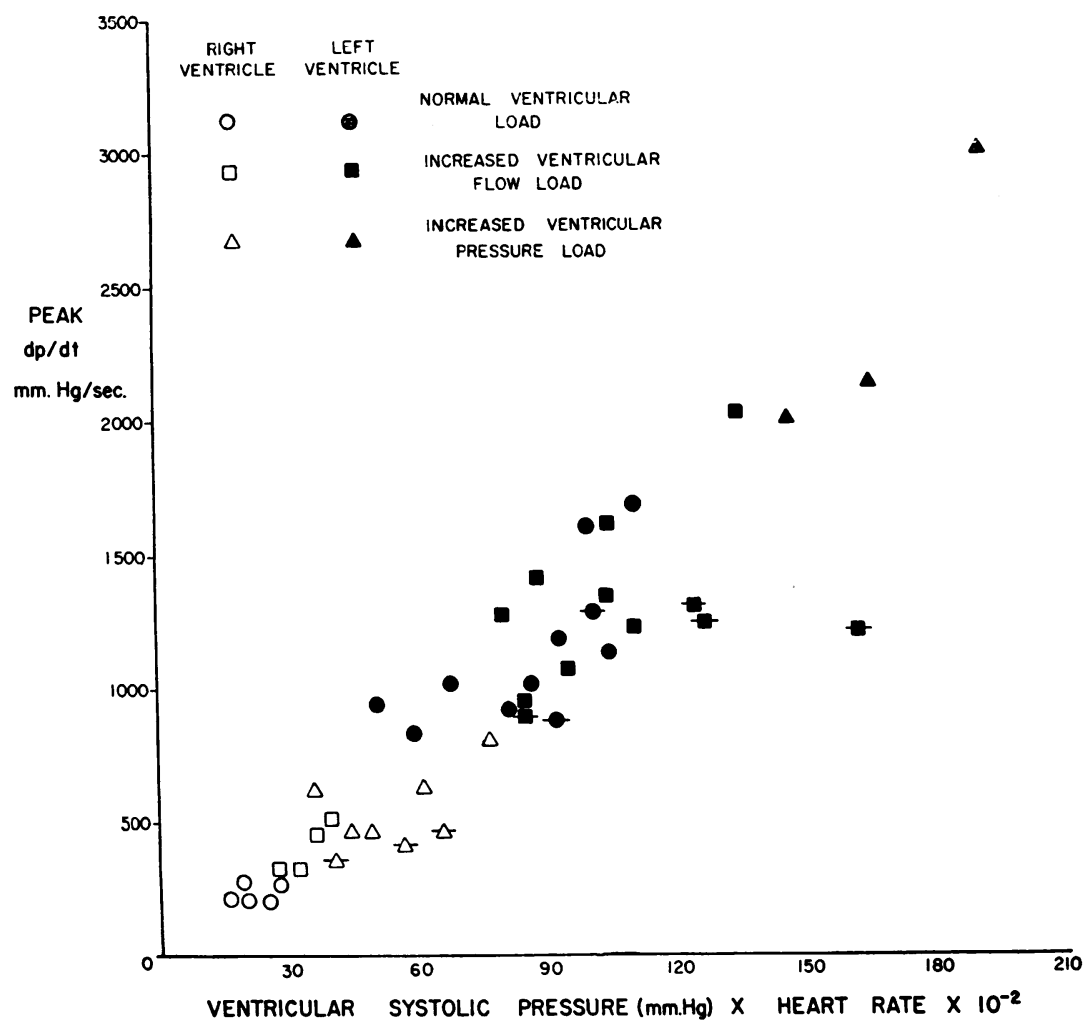

Fig. 4. Relationship between PD and the PROduCt of Ventricular systolic PRESSURE AND HEART RATE. The symbols indicating the patients who had experienced heart failure are the same as in Figure 3, and the correlation coefficient and regression line which are shown were calculated without inclusion of the data from these patients; the formula for the regression line is: $\mathrm{PD}=0.157$ (systolic pressure $\times$ heart rate) -149 .

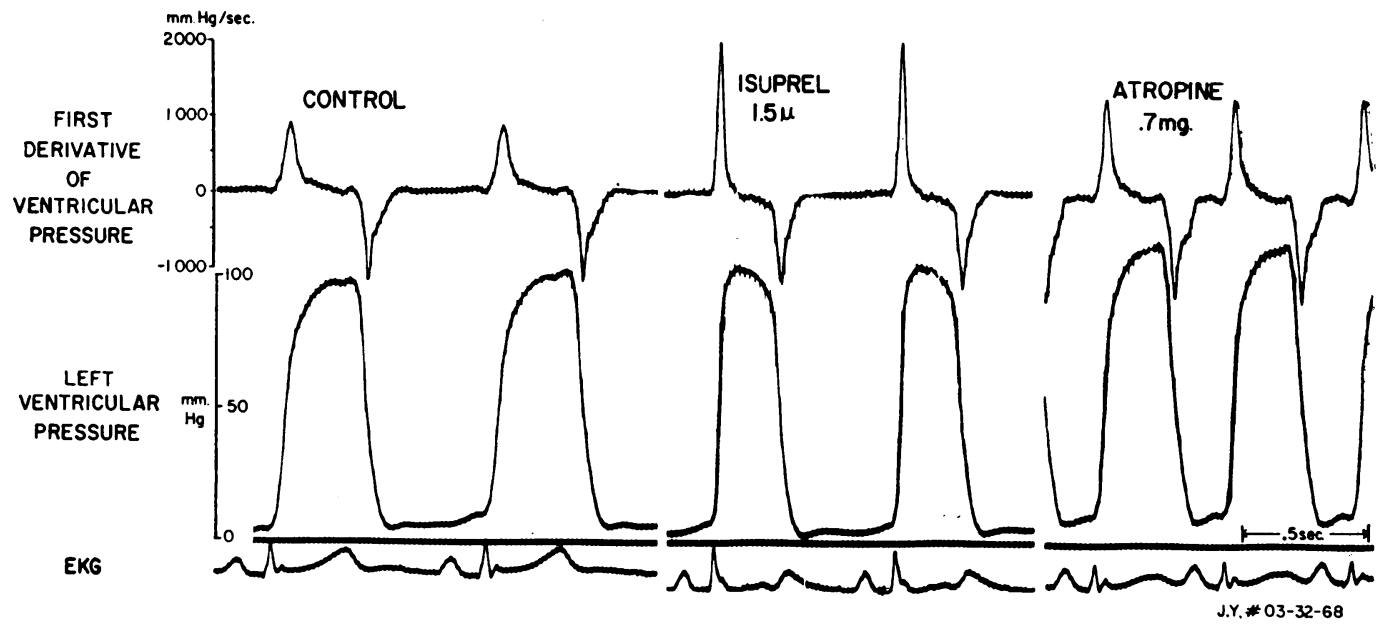

Fig. 5. SERIAL RECORDINGS OF LEFT ventricular PRESSURE AND OF DP/DT IN A 12 YeAR OLd GIRL With MILD PUlmonic valvular stenosis. The first record (control) is in the basal state, the middle record after the administration of $1.5 \mu \mathrm{g}$ isoproterenol (Isuprel), and the final record after $0.7 \mathrm{mg}$ atropine. 
TABLE III

Acute interventions *

\begin{tabular}{|c|c|c|c|c|c|c|}
\hline $\begin{array}{c}\text { Patient } \\
\text { Diagnosis }\end{array}$ & $\begin{array}{c}\text { Ventricle } \\
\text { studied } \\
\text { Method of study }\end{array}$ & Intervention & $\begin{array}{c}\text { Peak } \\
\mathrm{dp} / \mathrm{dt}\end{array}$ & $\begin{array}{l}\text { Peak } \\
-\mathrm{dp} / \mathrm{dt}\end{array}$ & $\begin{array}{l}\text { Heart } \\
\text { rate }\end{array}$ & $\begin{array}{l}\text { Ventricular } \\
\text { pressure s/d }\end{array}$ \\
\hline $\begin{array}{l}\text { J.Y. } \\
\text { ASD }\end{array}$ & $\begin{array}{l}\mathrm{LV} \\
\mathrm{TC}\end{array}$ & $\begin{array}{l}\text { Control } \\
\text { Methoxamine, } 2.4 \mathrm{mg} \\
\text { Control } \\
\text { Isuprel, } 1.5 \mu \mathrm{g} \dagger \\
\text { Control } \\
\text { Norepineph., } 2.4 \mu \mathrm{g} \\
\text { Control } \\
\text { Atropine, } 0.7 \mathrm{mg}\end{array}$ & $\begin{array}{r}841 \\
881 \\
863 \\
2,425 \\
920 \\
1,456 \\
845 \\
1,370\end{array}$ & $\begin{array}{l}1,110 \\
1,260 \\
1,260 \\
1,230 \\
1,220 \\
1,330 \\
1,180 \\
1,500\end{array}$ & $\begin{array}{r}71 \\
45 \\
72 \\
100 \\
74 \\
50 \\
72 \\
119\end{array}$ & $\begin{array}{c}83 / 8 \\
122 / 18 \\
93 / 6 \\
100 / 6 \\
99 / 11 \\
151 / 11 \\
93 / 8 \\
109 / 11\end{array}$ \\
\hline $\begin{array}{l}\text { C.W.C. } \\
\text { ASD }\end{array}$ & $\begin{array}{l}\text { LV } \\
\text { TC }\end{array}$ & $\begin{array}{l}\text { Control } \\
\text { Isuprel, } 1.5 \mu \mathrm{g} \\
\text { Control } \\
\text { Methox., } 2 \mathrm{mg} \\
\text { Control } \\
\text { Atropine, } 1 \mathrm{mg}\end{array}$ & $\begin{array}{r}943 \\
1,228 \\
835 \\
737 \\
750 \\
1,372\end{array}$ & $\begin{array}{r}661 \\
675 \\
780 \\
960 \\
870 \\
1,290\end{array}$ & $\begin{array}{r}58 \\
59 \\
58 \\
51 \\
54 \\
112\end{array}$ & $\begin{array}{l}87 / 9 \\
105 / 8 \\
101 / 11 \\
126 / 9 \\
115 / 11 \\
138 / 5\end{array}$ \\
\hline $\begin{array}{l}\text { M.J.S. } \\
\text { ASD }\end{array}$ & $\begin{array}{l}\text { LV } \\
\text { TC }\end{array}$ & $\begin{array}{l}\text { Control } \\
\text { Methox., } 2 \mathrm{mg} \\
\text { Isuprel, } 1.5 \mu \mathrm{gi} \\
\text { Atropine, } 1 \mathrm{mg}\end{array}$ & $\begin{array}{r}938 \\
994 \\
1,197 \\
1,008\end{array}$ & $\begin{array}{r}915 \\
980 \\
1,040 \\
1,060\end{array}$ & $\begin{array}{r}86 \\
79 \\
86 \\
111\end{array}$ & $\begin{array}{r}96 / 6 \\
111 / 5 \\
111 / 3 \\
98 / 1\end{array}$ \\
\hline $\begin{array}{l}\text { J.V.G. } \\
\text { Postop } \\
\text { ADS }\end{array}$ & $\begin{array}{l}\mathrm{RV} \\
\mathrm{TC}\end{array}$ & $\begin{array}{l}\text { Control } \\
\text { Atropine, } 1 \mathrm{mg}\end{array}$ & $\begin{array}{l}295 \\
318\end{array}$ & $\begin{array}{l}249 \\
267\end{array}$ & $\begin{array}{r}83 \\
106\end{array}$ & $\begin{array}{l}33 / 0 \\
29 / 0\end{array}$ \\
\hline $\begin{array}{l}\text { L.C.J. } \\
\text { MS; TS }\end{array}$ & $\begin{array}{l}\mathrm{RV} \\
\mathrm{TC}\end{array}$ & $\begin{array}{l}\text { Control } \\
\text { Isuprel, } 1.5 \mu \mathrm{g} \\
\text { Control } \\
\text { Methox., } 1 \mathrm{mg} \\
\text { Control } \\
\text { Atropine, } 1 \mathrm{mg}\end{array}$ & $\begin{array}{l}230 \\
453 \\
196 \\
189 \\
239 \\
298\end{array}$ & $\begin{array}{l}220 \\
254 \\
230 \\
225 \\
228 \\
304\end{array}$ & $\begin{array}{l}77 \\
79 \\
68 \\
63 \\
75 \\
95\end{array}$ & $\begin{array}{l}25 / 3 \\
32 / 3 \\
23 / 0 \\
25 / 2 \\
22 /-2 \\
23 / 0\end{array}$ \\
\hline $\begin{array}{l}\text { J.P.H. } \\
\text { ASD }\end{array}$ & $\begin{array}{l}\mathrm{LV} \\
\mathrm{TC}\end{array}$ & $\begin{array}{l}\text { Control } \\
2 \text { min. exercise }\end{array}$ & $\begin{array}{l}1,009 \\
1,948\end{array}$ & $\begin{array}{l}1,070 \\
1,390\end{array}$ & $\begin{array}{r}88 \\
111\end{array}$ & $\begin{array}{r}99 / 7 \\
122 / 7\end{array}$ \\
\hline $\begin{array}{l}\text { L.B.H. } \\
\text { Funct M }\end{array}$ & $\begin{array}{l}\mathrm{RV} \\
\mathrm{TC}\end{array}$ & $\begin{array}{l}\text { Control } \\
2 \text { min. exercise }\end{array}$ & $\begin{array}{l}165 \\
297\end{array}$ & $\begin{array}{l}126 \\
214\end{array}$ & $\begin{array}{r}99 \\
130\end{array}$ & $\begin{array}{l}22 / 5 \\
26 / 3\end{array}$ \\
\hline $\begin{array}{l}\text { J.G.P. } \\
\text { ASD }\end{array}$ & $\begin{array}{l}\mathrm{LV} \\
\mathrm{TC}\end{array}$ & $\begin{array}{l}\text { Control } \\
2 \text { min. exercise }\end{array}$ & $\begin{array}{r}960 \\
1,520\end{array}$ & & $\begin{array}{r}73 \\
102\end{array}$ & $\begin{array}{l}105 / 9 \\
120 / 9\end{array}$ \\
\hline \multirow{2}{*}{$\begin{array}{l}\text { J.B. } \\
\text { PDA; } \\
\text { coarc. }\end{array}$} & $\begin{array}{l}\mathrm{LV} \\
\text { OR }\end{array}$ & Ductus closed & 2,629 & 3,850 & 89 & $191 / 12$ \\
\hline & & Ductus opened & 2,950 & 3,520 & 103 & $178 / 18$ \\
\hline \multirow{2}{*}{$\begin{array}{l}\text { T.B. } \\
\text { PDA }\end{array}$} & \multirow{2}{*}{$\begin{array}{l}\mathrm{LV} \\
\mathrm{OR}\end{array}$} & Ductus closed & 1,300 & 1,390 & 65 & $145 / 12$ \\
\hline & & Ductus opened & 1,410 & 1,520 & 80 & $120 / 12$ \\
\hline \multirow{2}{*}{$\begin{array}{l}\text { C.M.F. } \\
\text { PDA }\end{array}$} & \multirow{2}{*}{$\begin{array}{l}\text { LV } \\
\text { OR }\end{array}$} & Ductus closed & 2,030 & 2,920 & 128 & $111 / 9$ \\
\hline & & Ductus opened & 2,040 & 2,840 & 129 & $105 / 11$ \\
\hline \multirow{2}{*}{$\begin{array}{l}\text { M.Y.J. } \\
\text { PDA; } \\
\text { MI }\end{array}$} & $\begin{array}{l}\text { LV } \\
\text { OR }\end{array}$ & Ductus closed & 968 & 1,510 & 94 & $90 / 16$ \\
\hline & & Ductus opened & 768 & 1,210 & 98 & $78 / 17$ \\
\hline
\end{tabular}

* Abbreviations same as in Tables I and II, plus: PDA = patent ductus arteriosus; Coarc. = coarctation of aorta $;-\mathrm{dp} / \mathrm{dt}=$ maximum rate of fall of ventricular pressure.

$\dagger$ Isoproterenol. 
the PD in the four patients to whom it was administered, in spite of raising the left ventricular end-diastolic pressure (Figure 6). One patient received norepinephrine in addition to isoproterenol and methoxamine; this drug elevated the PD but to a lesser degree than isoproterenol (Patient J. Y., Table III, Figures 5 and 6). Atropine, administered intravenously to five patients in doses of 0.7 to $1.0 \mathrm{mg}$, raised the heart rate by an average of 33 beats per minute and elevated the PD by values ranging from 7 to 83 per cent of the control values; the magnitude of the increase in the $P D$ was related to the increase in heart rate (Table III).

b) Exercise. In the patients in whom the effects of exercise were studied, the $\mathrm{PD}_{\mathrm{LV}}$ (two patients) and the $P D_{R V}$ (one patient) were greatly augmented (Table III).

c) Effects of opening a patent ductus arteriosus. Immediately after the ductus was opened a significant increase in heart rate occurred in two patients, and in them a modest augmentation of $\mathrm{PD}_{\mathrm{LV}}$ was observed. In the other two patients no significant change in heart rate occurred; $\mathrm{PD}_{\mathrm{LV}}$ fell slightly in one, and remained unchanged in the other (Table III).

d) Beat-to-beat changes in PD in atrial fibrillation. It was consistently observed that the $\mathrm{PD}_{\mathrm{LV}}$ varied with the interval between successive $Q R S$ complexes. Furthermore, the peak left ventricular systolic pressure and the aortic pulse pressure were directly proportional to the $\mathrm{PD}_{\mathrm{LV}}$; i.e., when the rate of left ventricular pressure rise was rapid, the peak systolic pressure and pulse pressure which were developed tended to be greater than when the $P D_{L V}$ was relatively low. The results obtained in one patient are plotted in Figure 7 and are representative of those observed in the eight patients with atrial fibrillation who were studied.

e) Ventricular premature contractions. Four patients developed an occasional premature ventricular contraction in the course of the study. In each instance the $\mathrm{PD}$ of the premature contraction was significantly smaller than that observed during normal beats.

\section{Negative $P D$}

The maximum rate of decline of the ventricular pressure (negative PD) was usually of an order of magnitude similar to the PD of the ascending limb of the same ventricular pressure pulse. Interventions that increased myocardial contractility (e.g., intravenous isoproterenol, Figure 5) had little effect on the negative PD in spite of their striking augmentation of the positive $\mathrm{PD}$. On the other hand, an acutely induced increase in the peak ventricular pressure or increase in heart rate tended to augment the negative PD (Table III).

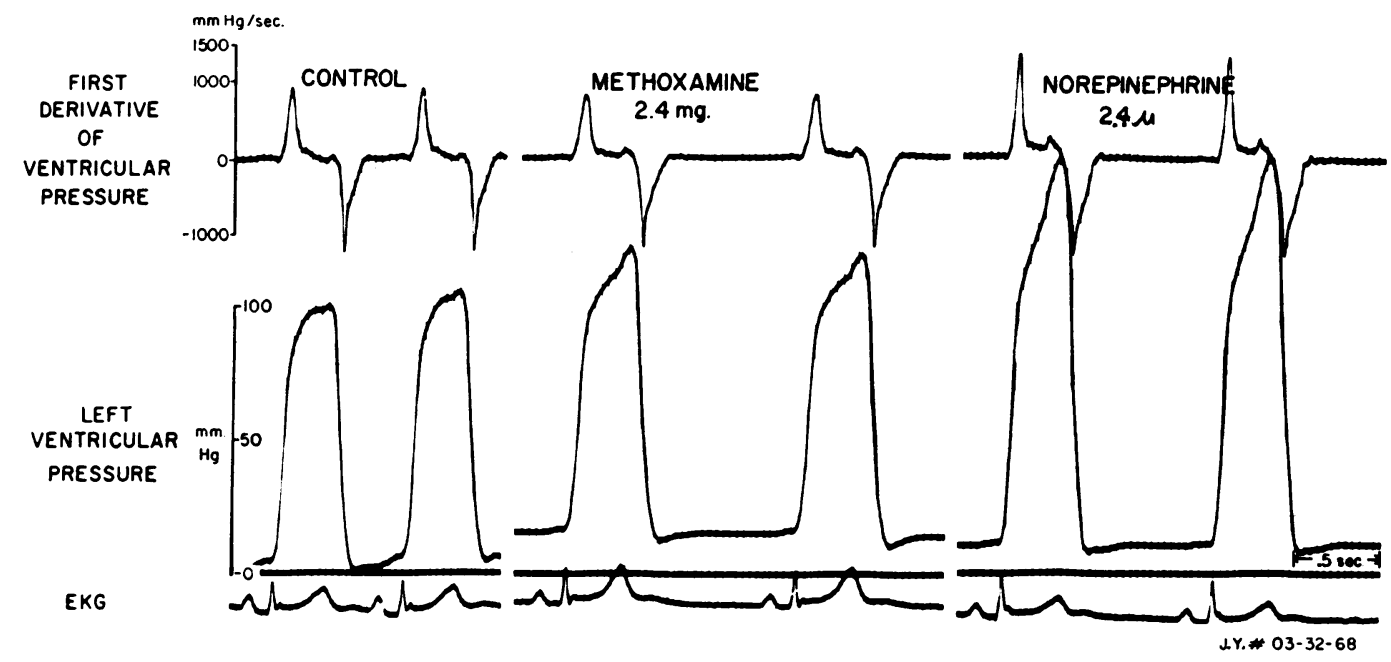

Fig. 6. Serial ReCordings of Left ventricular PRESSURE AND OF DP/DT IN THE SAME PATIENT AS IN FIGURE 5. The tracings obtained in the control state are on the left, after methoxamine injection in the middle, and after norepinephrine injection on the right. These recordings were obtained at a slower paper speed than those reproduced in Figure 5. 
L.V. PEAK $d p / d t$ IN ATRIAL FIBRILLATION

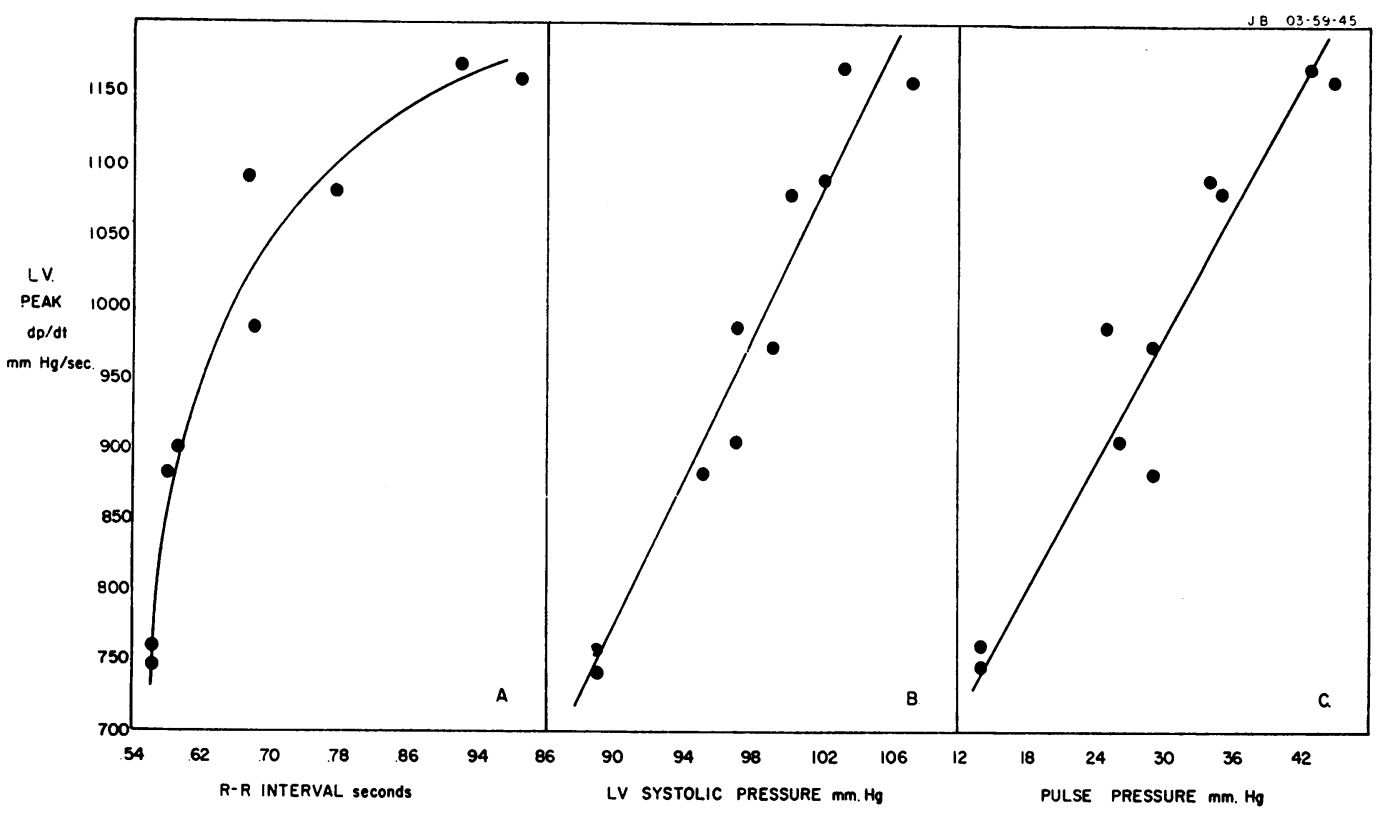

Fig. 7. Graphs illustrating the relationship between the left ventricular PD and (A) the PRECEDING R-R INTERVAL; (B) THE LV SYSTOLIC PRESSURE; (C) THE BRACHIAL ARTERIAL PULSE PRESSURE OF THE SAME BEAT IN A PATIENT WITH RHEUMATIC MITRAL VALVE DISEASE AND ATRIAL FIBRILLATION.

\section{DISCUSSION}

Sarnoff and Mitchell have recently defined an increase of myocardial contractility as occurring "when from any given end-diastolic pressure or fiber length, the ventricle produces more external stroke work and more stroke work per systolic second. Implicit in this definition is an increased rate of development of tension when contractility increases" (17). Rushmer, Smith and Franklin have demonstrated an increase in the rate of pressure development in the left ventricle when myocardial contractility was augmented by the administration of catecholamines, by muscular exercise, or by hypothalamic stimulation (18). The observations of these and other investigators (1-11) are all compatible with the view that the rate at which ventricular pressure is developed reflects a fundamental property of contracting myocardium. Accordingly, it was thought that measurement of this parameter would provide an approach to the study of ventricular contractility in intact, unanesthetized man.

It is well established that certain sympathomimetic amines. such as isoproterenol and norepinephrine, augment myocardial contractile force, while others, such as methoxamine, fail to do so $(19,20)$. It could thus be anticipated that if changes in the PD reflected changes in myocardial contractility, the rate of pressure rise should be elevated by administration of the cardioactive sympathomimetic amines, but not modified by the drugs that have no direct cardiac effects; this indeed was found to be the case (Figure 5). It was also demonstrated that muscular exercise and atropine-induced tachycardia raised the PD. The increase noted with tachycardia may be analogous to the so-called "treppe" phenomenon, described by Bowditch (21).

Siegel and Sonnenblick, utilizing an isovolumetrically-beating ventricle, as well as a cat papillary muscle preparation, have demonstrated that rate of development of tension is dependent on the length of the muscle fiber at the onset of contraction (8). In patients with mitral valve disease and atrial fibrillation, variations in the duration of diastole result in alterations in the degree of ventricular filling and, therefore, in the ventricular end-diastolic volume and fiber length (22). In the present study good correlations between the $\mathrm{PD}$ and the duration of the filling period (Figure 
$7, A)$, the peak sytolic ventricular pressure (B) and the arterial pulse pressure (C) were observed. These observations suggest that in these patients with mitral stenosis and atrial fibrillation, the PD correlates closely with the end-diastolic fiber length during a series of consecutive cardiac cycles.

Unlike the effects of acute elevations of ventricular end-diastolic volume, hemodynamic abnormalities which result in a chronic augmentation of ventricular stroke volume did not result in abnormal values of the $\mathrm{PD}$. In contrast, the PD correlated well with the peak systolic pressure chronically developed by the ventricle, and in this correlation both ventricles fell on the same regression line (Figure 3). A number of factors may be involved in this relationship. Sandler, Dodge and Hay have recently presented evidence indicating that the thickness of the ventricular wall increases in proportion to the systolic pressure which is chronically developed by the ventricle (23). Taking the chamber size and wall thickness into consideration they have calculated that the tension developed by each unit of myocardium tends to remain constant, regardless of the level of systolic pressure which the ventricle sustains. In patients with a ventricular "pressure load" and an increased muscle mass of hypertrophied myocardium, the elevated systolic pressure is developed in the same time interval that is required by the normal myocardium to reach a normal ventricular systolic pressure. In view of these findings of Sandler and co-workers, it is possible that the rates of development of tension of each myocardial unit are similar in the normal and in the hypertrophied heart. Accordingly, it may be postulated that the relatively high PD's observed in ventricles that developed elevated pressures reflect the increased muscle mass which is present. The differences in the PD's observed between the two ventricles in the patients without hemodynamic abnormalities could also be similarly explained.

The correlation between PD and peak systolic pressure was improved slightly when rate was also taken into consideration (Figure 4). It is likely that the sympathetic stimulation of myocardial contractility was greater in patients with rapid heart rates than in those with slower rates, and that this effect, as well as the stimulation of myocardial contractility provided by an increase in heart rate per se-i.e., by the "treppe" phenomenon $(21,24)$-was responsible for the improvement in this correlation.

The patients who had experienced congestive heart failure and had roentgenographic evidence of left ventricular enlargement and elevation of the ventricular end-diastolic pressure, tended to have lower PD's than might have been anticipated by their systolic ventricular pressure and heart rate (Figures 3 and 4). Two explanations for this finding may be advanced. First, when the law of Laplace (25) is considered, it is apparent that any given rate of development of tension by the myocardium would result in a slower rate of pressure rise and, hence, in a lower PD in a dilated than in a normal-sized heart. Second, it is possible that the depression of myocardial contractility which may have been present in these patients is responsible for their lowered PD's. In support of this view are the demonstrations by Wiggers in the dog with an intact circulation (6) and by Buckley and Zeig in an isolated heart preparation (10) that acute left ventricular failure is accompanied by a decrease in the rate of ventricular pressure rise. Regardless of the specific mechanism responsible for lowering the $\mathrm{PD}$ in patients with congestive heart failure, it is possible that analysis of the first derivative of the ventricular pressure pulse may provide a simple means of quantifying depressed ventricular function in man.

The findings in this investigation are not consonant with the general impression (26) that the rate at which ventricular pressure falls usually parallels the rate at which it rises (26) (Table III). However, Zeig, Buckley and Porter have recently shown that contraction and relaxation can be altered independently by acutely changing ventricular work loads (11).

\section{SUM MARY}

Since observations in experimental animals have suggested that the rate at which ventricular pressure rises is a function of myocardial contractility, it was thought that determination of the rate of change of ventricular pressure might permit study of myocardial contractility in intact man. The first derivative of the ventricular pressure pulse was continuously computed by means of an electronic differentiating circuit in 40 patients. In order to avoid the artifacts inherent in pressures 
measured by means of standard catheter-manometer systems, these studies were confined to pressures obtained from a catheter with a high-fidelity micromanometer mounted at its tip or by puncture of the ventricle with the manometer directly attached to the needle. The peak first derivative (maximum rate of pressure rise) in patients without hemodynamic abnormalities ranged between 841 and $1,696 \mathrm{~mm} \mathrm{Hg}$ per second in the left ventricle, and between 223 and 296 in the right ventricle. Interventions which acutely augmented myocardial contractility, such as muscular exercise, isopropyl norepinephrine, norepinephrine, and atropine, resulted in striking increases in the peak derivative. Beat-to-beat changes in ventricular filling in patients with atrial fibrillation produced changes in the peak derivative which suggested that the latter parameter was also dependent upon ventricular end-diastolic volume. In the control state the peak derivative in both ventricles demonstrated a linear correlation with the peak systolic pressure and a somewhat better correlation with the product of systolic pressure and heart rate.

\section{ACKNOWLEDGMENT}

The cooperation of Dr. Andrew G. Morrow, who obtained the pressure tracings at the operating table, is gratefully acknowledged. Mr. Frank Noble, of the Laboratory of Technical Development, National Heart Institute, designed the sine-wave generator and the differentiating circuit and provided helpful technical advice throughout this study.

\section{REFERENCES}

1. Frank, O. On the dynamics of cardiac muscle (C. B. Chapman, and E. Wasserman, Trans.). Amer. Heart J. 1959, 58, 282.

2. Patterson, S. W., Piper, H., and Starling, E. H. The regulation of the heart beat. J. Physiol. (Lond.) 1914, 48, 465.

3. Wiggers, C. J. Studies on the cardiodynamic actions of drugs. I. The application of the optical methods of pressure registration in the study of cardiac stimulants and depressants. J. Pharmacol. exp. Ther. 1927, 30, 217.

4. Wiggers, C. J. Studies on the cardiodynamic actions of drugs. II. The mechanism of cardiac stimulation by epinephrin. J. Pharmacol. exp. Ther. 1927, $30,233$.

5. Wiggers, C. J., and Stimson, B. Studies on the cardiodynamic actions of drugs. III. The mechanism of cardiac stimulation by digitalis and g-strophanthin. J. Pharmacol. exp. Ther. 1927, 30, 251.
6. Wiggers, C. J. Dynamics of ventricular contraction under abnormal conditions. Circulation 1952, 5, 321.

7. Reeves, T. J., Hefner, L. L., Jones, W. B., Coghlan, C., Prieto, G., and Carroll, J. The hemodynamic determinants of the rate of change in pressure in the left ventricle during isometric contraction. Amer. Heart J. 1960, 60, 745.

8. Siegel, J. H., and Sonnenblick, E. H. A dynamic index characterizing alterations in the basic state of cardiac muscle. Circulat. Res. In press.

9. Tolman, R. A., and Young, P. G. Slope changes of ventricular pressure curves compared with ventricular function curves. Fed. Proc. 1961, 20, 124.

10. Buckley, N. M., and Zeig, N. J. Acute unilateral ventricular failure in the isolated dog heart. Amer. J. Physiol. 1959, 197, 247.

11. Zeig, N. J. Buckley, N. M., and Porter, E. P. Effects of work loads applied at various times in the cardiac cycle of the isolated dog heart. Circulat. Res. 1961, 9, 531.

12. Brock, R., Milstein, B. B., and Ross, D. N. Percutaneous left ventricular puncture in the assessment of aortic stenosis. Thorax 1956, 11, 163.

13. Brockenbrough, E. C., Morrow, A. G., Talbert, J., and Braunwald, E. Percutaneous puncture of the left ventricle. Brit. Heart J. In press.

14. Laurens, P., Bouchard, P., Brial, E., Cornu, C., Basculard, P., and Soulié, P. Bruits et pressions cardio-vasculaires enregistrés in situ à l'aide d'un micromanomètre. Arch. Bal. Coeur 1959, 52, 121.

15. Allard, E. M. Construction et utilisation des capteurs de pression in Proc. Second Int. Conf. on Medical Electronics, C. N. Smyth, Ed. London, Ilffe, 1960, p. 263.

16. Noble, F. W. Electrical Methods of Blood-pressure Recordings. Springfield, I11., Thomas, 1953, p. 40.

17. Sarnoff, S. J., and Mitchell, J. H. The regulation of the performance of the heart. Amer. J. Med. 1961, 30, 747.

18. Rushmer, R. F., Smith, O., and Franklin, D. Mechanisms of cardiac control in exercise. Circulat. Res. 1959, 7, 602.

19. Goldberg, L. I., Cotten, M. de V., Darby, T. D., and Howell, E. V. Comparative heart contractile force effects of equipressor doses of several sympathomimetic amines. J. Pharmacol. exp. Ther. 1953, 108, 177.

20. Goldberg, L. I., Bloodwell, R. D., Braunwald, E., and Morrow, A. G. The direct effects of norepinephrine, epinephrine, and methoxamine on myocardial contractile force in man. Circulation 1960, 22, 1125.

21. Bowditch, H. P. Uber die Eigenthumlichkeiten der Reizarbeit, welche die Muskelfasern des Herzens zeigen. Ber. Verh. der kongiglich sachsischen ges. Wissenschaften zu Leipzig 1871, 23, 652. 
22. Braunwald, E., Frye, R. L., Aygen, M. M., and Gilbert, J. W., Jr. Studies on Starling's law of the heart. III. Observations in patients with mitral stenosis and atrial fibrillation on the relationships between left ventricular end-diastolic segment length, filling pressure, and characteristics of ventricular contraction. J. clin. Invest. 1960, 39, 1874.

23. Sandler, H., Dodge, H., and Hay, R. Left ventricular tension and stress in man. Clin. Res. 1961, 9, 145.
24. Sarnoff, S. J., Mitchell, J. H., Gilmore, J. P., and Remensnyder, J. P. Homeometric autoregulation in the heart. Circulat. Res. 1960, 8, 1077.

25. Rushmer, R. F. Cardiovascular Dynamics, 2nd ed. Philadelphia, Saunders 1961, p. 69.

26. Wiggers, C. J., and Maltby, A. B. Further observations on experimental aortic insufficiency. IV. Hemodynamic factors determining the characteristic changes in aortic and ventricular pressure pulses. Amer. J. Physiol. 1931, 97, 689. 